\title{
Retrospective assessment of the quality of diabetes care in a rural diabetes clinic in Western Kenya
}

\author{
Sonak D. Pastakia ${ }^{1,2,3,4^{*}}$, Bernardo Nuche-Berenguer ${ }^{5}$, Chelsea Regina Pekny ${ }^{6}$, Benson Njuguna ${ }^{2}$, \\ Elizabeth Guinevere O'Hara ${ }^{7}$, Stephanie Y. Cheng ${ }^{3}$, Jeremiah Laktabai ${ }^{1,2,4}$, Victor Buckwalter ${ }^{4}$, Nicholas Kirui ${ }^{2}$ \\ and Patrick Chege ${ }^{1,4}$
}

\begin{abstract}
Background: Sub-Saharan Africa continues to face the highest rate of mortality from diabetes in the world due to limited access to quality diabetes care. We assessed the quality of diabetes care in a rural diabetes clinic in western Kenya.

Methods: To provide a comprehensive assessment, a set of clinical outcomes, process, and structure metrics were evaluated to assess the quality of diabetes care provided in the outpatient clinic at Webuye District Hospital. The primary clinical outcome measures were the change in $\mathrm{HbA1c}$ and point of care blood glucose. In assessing process metrics, the primary measure was the percentage of patients who were lost to follow up. The structure metrics were assessed by evaluating different facets of the operation of the clinic and their accordance with the International Diabetes Federation (IDF) guidelines.

Results: A total of 524 patients were enrolled into the diabetes clinic during the predefined period of evaluation. The overall clinic population demonstrated a statistically significant reduction in $\mathrm{HbA1c}$ and point of care blood glucose at all time points of evaluation after baseline. Patients had a mean baseline HbA1C of $10.2 \%$ which decreased to $8.4 \%$ amongst the patients who remained in care after 18 months. In terms of process measures, 38 patients (7.3\%) were characterized as being lost to follow up as they missed clinic visits for more than 6 months. Through the assessment of structural metrics, the clinic met at least the minimal standards of care for 14 out of the 19 domains recommended by the IDF.
\end{abstract}

Conclusion: This analysis illustrates the gains made in various elements of diabetes care quality which can be used by other programs to guide diabetes care scale up across the region.

Keywords: Diabetes, Diabetes care, Rural, Sub-saharan Africa, Non-communicable disease

\section{Background}

Diabetes mellitus (DM) is a leading cause for cardiovascular disease (CVD), death and disability in sub-Saharan Africa (SSA). Prevalence of DM in SSA is 7.1\% [1], while awareness, treatment and control rates are low [2], with $75 \%$ of diabetes related deaths in SSA occurring before the age of 60 , a significant blow to a productive population [3]. These

\footnotetext{
* Correspondence: spastaki@gmail.com

${ }^{1}$ Moi University School of Medicine, Nandi Hills Road, Eldoret 30100, Kenya

${ }^{2}$ USAID-Academic Model Providing Access to Healthcare (AMPATH) /Moi

Teaching and Referral Hospital, Nandi Hills Road, Eldoret 30100, Kenya

Full list of author information is available at the end of the article
}

dire statistics reflect a sub-optimal infrastructure for DM care in SSA, which needs to be urgently strengthened, particularly given estimates that the prevalence of DM in SSA is expected to more than double by 2045 [3].

Effective diabetes care requires reliable access to recommended diagnosis, treatment, and monitoring for hyperglycemia. There is limited availability of recommended tests for hyperglycemia such as fasting blood glucose [3] measurement, while simpler less, accurate methods for diagnosis such as point-of-care capillary testing are hampered by low availability of glucose strips [2]. Availability of the basic drugs for treatment of

(c) The Author(s). 2018 Open Access This article is distributed under the terms of the Creative Commons Attribution 4.0 International License (http://creativecommons.org/licenses/by/4.0/), which permits unrestricted use, distribution, and 
diabetes such as metformin, sulfonylureas, and insulin is reportedly low, while treatment monitoring is sub-optimal given the low access to fasting glucose testing and glycated hemoglobin (HbA1C) testing. Additionally, there are potential inaccuracies associated with $\mathrm{HbA1C}$ testing in SSA populations. While emphasis on the rapid growth and high mortality burden of diabetes has focused on densely populated urban areas where prevalence is highest [4], these inadequacies are likely compounded in rural SSA populations where even less human and supply chain resources exist $[2,5,6]$. For instance, insulin is available less than $8 \%$ of the time in many SSA rural regions. Clinical outcomes are therefore worse, as exemplified by reports of an average life expectancy in rural areas of less than 1 year for children diagnosed with type 1 diabetes $[4,7,8]$. With $61 \%$ of the SSA population residing in rural areas, there is an urgent need to rapidly scale up access to high quality diabetes care in these settings. [6, 8-10]

The International Diabetes Federation (IDF) has provided global guidelines for diabetes care which include a set of minimum standards of care that recognise the dearth of resources available in low resource settings [11]. This guideline provides recommendations for the minimal, basic, and comprehensive standards of care which programs should strive for when developing responsive and effective diabetes care programs. These domains include screening, care delivery, education, psychological care, lifestyle management, glucose control targets, clinical monitoring, glucose control with oral therapy, glucose control with insulin therapy, blood pressure control, cardiovascular risk protection, eye screening, kidney damage, foot care, nerve damage, pregnancy, children, and in-patient care. Additional details can be found in the Additional file 1: Figure S1.

In order to respond to these comprehensive diabetes care needs, stakeholders have collaborated to improve diabetes care in rural western Kenya. The Academic Model Providing Access to Healthcare (AMPATH) has established a comprehensive care model for diabetes and other non-communicable diseases (NCDs) that leverages robust existing human immunodeficiency virus (HIV) care infrastructure developed in collaboration with The United States Agency for International Development (USAID). AMPATH is a partnership between Moi University, Moi Teaching and Referral Hospital (Eldoret, Western Kenya) and a consortium of North American universities led by the Indiana University School of Medicine [12]. In collaboration with the Kenyan Ministry of Health $(\mathrm{MOH})$ and Moi Teaching and Referral Hospital, AMPATH has addressed fundamental supply chain and human resource barriers to access for diabetes care in rural Western Kenya [5, 13].
We established a diabetes clinic in Western Kenya, with care standardized in accordance to the IDF global guidelines, and adapted for rural diabetes care through protocols aimed at achieving the minimum recommended standards of care [11]. The aim of this article is to determine the quality of diabetes care by describing relevant clinical, process, and structural outcomes in a rural diabetes clinic in SSA.

\section{Methods}

\section{Study design, and setting}

We conducted a retrospective study in the diabetes clinic of Webuye District Hospital (WDH), a secondary care hospital in rural Western Kenya. The clinic was established in 2009 and serves a low-income population that primarily relies on an agriculture-based economy and job market. The clinic is regularly staffed by clinical officers (diploma level providers equivalent to physician assistants in other settings), nutrition counselors, and a social work team. Clinical officers manage stable patients, defined as patients with well controlled diabetes and low risk for complications, while family medicine residents and consultant physicians review newly enrolled patients. In addition, the physicians, family medicine residents and clinical pharmacists provide care decision support for complicated cases. Patients are scheduled for follow up anytime between one week and three months depending on the patient's clinical needs. The clinic is able to provide both insulin therapy, oral hypoglycemic agents (sulfonylureas), and metformin, as well as routine tests such as point-of-care blood glucose (Abbott Optimum Xceed ${ }^{\circ}$ ), and glycated hemoglobin (HbA1C, Siemens DCA Vantage $\left.{ }^{\circ}\right)$ at the clinic. The hospital lab provides urea, creatinine, electrolyte measurements, urinalysis, and complete blood count testing, when needed. Insulin dependent patients and/or those at increased risk of diabetes related complications are eligible for inclusion within an intensive self-monitored blood glucose (SMBG) program where patients are provided with glucose monitoring devices and test strips for twice daily SMBG checks and relay them to the clinic once a week via phone calls for dose adjustments by the clinic staff [14]. Patients with additional diagnostic tests or treatment requirements beyond the hospital's capacity are referred to higher levels of care or private facilities. Clinic and phone based patient encounters are recorded using paper based forms that are transcribed into an electronic database. [11].

This study was approved by the Moi Teaching and Referral Hospital/Moi University School of Medicine Institutional Research and Ethics Committee and the Institutional Review Board of the Indiana University Purdue University Indianapolis (IUPUI). A waiver of informed consent was obtained from both of the institutions 
as all data being assessed was collected through routine clinical care and was de-identified before being retrospectively assessed.

\section{Participants and data collection}

We included data from all patients with type 1 or type 2 diabetes who received care in the WDH diabetes clinic between July 2009 and September 2011. Data was abstracted from the clinic's electronic database using a predesigned data collection tool by a trained data manager who also checked the information for completeness and discrepancies by periodically comparing the information to the paper-based records.

Baseline data collected for all patients included demographic and socio-economic data. We collected the following information available for each clinical encounter: random blood sugar (RBS), HbA1C, body mass index (BMI), systolic and diastolic blood pressure, self-reported signs and symptoms of hyperglycemia or hypoglycemia (polyuria, polydipsia, polyphagia, change in vision, loss of consciousness, confusion, diaphoresis, weakness, shaking, dizziness, and headache), self-reported symptoms of peripheral neuropathy (skin numbness, tingling, hot/cold or burning sensation) or peripheral neuropathy detected by use of a $10 \mathrm{~g}$ monofilament test on each foot, ocular problems (blurred or cloudy vision, eye itchiness, myopia, and hypermetropia), and prescribed medications. For male patients, data on symptoms of impotence were also collected. Where available, data points were collected for each 3-month clinic visit, up to a period of 18 months after enrollment for each individual patient.

\section{Outcomes}

We considered clinical outcomes, process, and structure metrics when assessing the quality of diabetes care at WDH. The primary clinical outcome of interest was change in HbA1C from baseline to 18 months. Secondary clinical outcomes included the change in HbA1c, blood glucose, BMI, blood pressure, and the frequency of diabetes complications at quarterly intervals. Diabetes complications specifically tracked within routine clinical care included symptomatic hypoglycemia/ hyperglycemia, presence of peripheral neuropathy, and ocular complications.

The primary process metric of interest was loss-to-follow up, defined as absence of clinical encounter data for more than six consecutive months, for an individual patient. Secondary process metrics included patterns of medication use and frequency of documentation of recommended diabetes care services. In addition, we compared service delivery at WDH against 19 different domains in the minimal, standard, and comprehensive care recommendations from the IDF Global Guideline for diabetes care [11].

\section{Statistical analysis}

Results were presented descriptively as percentages, means, and medians, with corresponding standard deviation and range, where appropriate. Means and standard deviations were presented for normally distributed data while medians and interquartile ranges were utilized for data with a skewed distribution. Comparison between baseline clinical data and subsequent data was made using the paired t-test, with statistical significance being set to a $p$ value $<0.05$. STATA 13.1(College Station, TX, USA) was used for all analyses.

\section{Results}

524 patients were enrolled in the WDH diabetes clinic between July 2009 and September 2011. Median age was 58 years $(\mathrm{IQR}=19)$ with only 14 patients $(3 \%$ of the population) having an age $\leq 20$ years and $56 \%$ being female. The median diabetes duration prior to enrolment was 4 years. Baseline mean BMI of the male and female participants were $26.0 \mathrm{~kg} / \mathrm{m}^{2}(\mathrm{SD}=9.0)$ and $27.6(\mathrm{SD}=$ 6.5) $\mathrm{kg} / \mathrm{m}^{2}$, respectively. $27 \%(n=95)$ of the evaluable population were obese (BMI $\geq 30 \mathrm{~kg} / \mathrm{m}^{2}$ ) with significantly more women $(31 \%, n=63)$ being obese than men $(21 \%, n=32)$. Of these 524 patients, 85 were enrolled into the SMBG program for intensive follow-up. Additional baseline characteristics are shown in Table 1 with more detailed descriptions available in a prior publication [15]. Within the 18-month period of database evaluation, $60 \%$ of the patients had follow up data for at least 6 months while $31 \%$ of patients had follow up data for at least 18 months (Table 2).

\section{Clinical outcomes}

Mean HbA1c decreased from a baseline of $10.2 \%$ by $10 \%$ for each subsequent clinic visit compared to the enrolment HbA1c. This reduction was statistically significant for each interval comparison for the SMBG group, the non-SMBG group (usual clinic care), and for the overall group. Significance was primarily driven by patients with higher baseline HbA1c (>10\%) who showed a statistically significant mean decrease of $31.6 \%$ at 12 months, while patients with an HbA1c between 7 and $10 \%$ showed a modest and non-significant mean decrease in HbA1c of $2.7 \%$. Participants in the SMBG group had the highest baseline $\mathrm{HbA1C}$ at $12.4 \%$ and showed the largest drop after 3 months of care to $9.6 \%$ (Table 3).

Mean blood sugar (based on random blood sugar obtained during the clinic visit) decreased from a baseline value of $10.7 \mathrm{mmol} / \mathrm{l}$ by $\geq 10 \%$ for each subsequent clinic visit compared to enrolment RBS. This trend, however, was only statistically significant when comparing months 3, 6, and 12 to the baseline RBS (Table 4).

Statistically significant reductions were not seen with systolic or diastolic blood pressure from the baseline 
Table 1 - Baseline demographic and clinical values

\begin{tabular}{|c|c|}
\hline Number of Patients & 524 \\
\hline Median Age (IQR) & $58(19)$ \\
\hline Median diabetes duration (IQR) & $4(18)$ \\
\hline \multicolumn{2}{|l|}{ Age category on enrollment in the clinic (years) } \\
\hline $11-15, \mathrm{n}(\%)$ & $7(1.5 \%)$ \\
\hline $16-20$ & $7(1.5 \%)$ \\
\hline $21-25$ & $10(2.1 \%)$ \\
\hline $26-30$ & $6(1.2 \%)$ \\
\hline $31-40$ & $24(5.0 \%)$ \\
\hline $41-50$ & $91(18.8 \%)$ \\
\hline $51-60$ & $130(26.9 \%)$ \\
\hline $61-70$ & $120(24.8 \%)$ \\
\hline $71-80$ & $71(14.67 \%)$ \\
\hline$>80$ & $18(3.7 \%)$ \\
\hline Female, n (\%) & $295(56.3 \%)$ \\
\hline Male, n (\%) & $229(43.7 \%)$ \\
\hline $\mathrm{HBA} 1 \mathrm{C}$ mean $\pm \mathrm{SEM}, \%$ & $10.2 \pm 2.8$ \\
\hline$<7 \%, \mathrm{n}(\%)$ & $63(15.0 \%)$ \\
\hline $7-10 \%$ & $150(35.6 \%)$ \\
\hline$>10 \%$ & $208(49.4 \%)$ \\
\hline Systolic blood pressure, mean \pm SD mmHg & $134 \pm 24$ \\
\hline Diastolic blood pressure, mean \pm SD mmHg & $83 \pm 12$ \\
\hline < 120/80 (Normal) n (\%) & $98(19.1 \%)$ \\
\hline 120-139/80-89 (Prehypertension) & $277(53.9 \%)$ \\
\hline 140-159/90-99 (Hypertension, Stage 1) & $112(21.8 \%)$ \\
\hline > 160/100 (Hypertension, Stage 2) & $27(5.3 \%)$ \\
\hline Mean BMI $\pm S D(K g / m 2)$ & $27.15 \pm 6.55$ \\
\hline Male, Mean BMI \pm SD (n) & $26.0 \pm 9.0(150)$ \\
\hline Female & $27.6 \pm 6.5(202)$ \\
\hline$<18.50, \mathrm{n}(\%)$ & $23(6.7 \%)$ \\
\hline $18.50-24.99$ & $108(31.1 \%)$ \\
\hline $25-29.99$ & $125(36.0 \%)$ \\
\hline Obese class I range of 30.00-34.99 & $52(15.0 \%)$ \\
\hline Obese class II range of 35.00-39.99 & $26(7.5 \%)$ \\
\hline$\geq 40.00$ & $13(3.8 \%)$ \\
\hline
\end{tabular}

SEM Standard Error of the Mean, SD Standard Deviation, IQR Interquartile range

mean blood pressure of $134 / 83 \mathrm{mmHg}$. Minimal and non-significant changes in the mean BMI were seen throughout the periods of evaluation. Among individuals with a baseline BMI $<18.5 \mathrm{~kg} / \mathrm{m}^{2}$, BMI increased over time to a mean BMI of $20 \mathrm{~kg} / \mathrm{m}^{2}$ by month 18 (Table 5).

In terms of diabetes complications, participants in both the SMBG and regular care groups demonstrated high initial frequencies at enrolment of peripheral neuropathy manifested primarily through foot symptoms, ocular complications, hypoglycemia, and hyperglycemia, which declined over time as illustrated in Table 6.

\section{Process outcomes}

$38(7.3 \%)$ patients in the overall clinical population were lost to follow-up, with their distribution being $6(7.1 \%)$ patients in the SMBG program and 32 patients $(7.3 \%)$ in usual clinic care. In terms of documentation of recommended diabetes care procedures, assessment for hypoglycemia and hyperglycemia, blood pressure, ophthalmological symptoms, and symptoms of foot disorders were documented for more than $90 \%$ of the clinic visits. $85.1 \%$ of the evaluable population had an $\mathrm{HbA} 1 \mathrm{c}$ result documented twice per year, $2.7 \%$ documented having their serum lipids checked at any time point, $1.5 \%$ had a creatinine result documented, and nobody had a documented microalbumin test.

A total of 284 patients (58\%) were on oral medication, 95 (19\%) were only taking insulin, 88 (18\%) were taking oral medications and insulin, $16(3 \%)$ were taking mostly oral medication but also insulin at some point in their care, and $6(1 \%)$ were taking mostly insulin but also received trials of oral medications. Patients with diabetes and hypertension were started on various hypertension medications with angiotensin converting enzyme inhibitors (enalapril) being prescribed for $73 \%$ of diabetes patients, followed by thiazide-type diuretics (hydrochlorothiazide) for $58 \%$ of patients, calcium channel blockers (nifedipine $30.5 \%$ and amlodipine $1 \%$ ), angiotensin receptor blockers (11\%), beta blockers (atenolol 11\%, carvedilol 2\%, and metoprolol 1.3\%), loop diuretics (furosemide 7.4\%), and aldosterone antagonists (spironolactone $1.1 \%)$. Low dose aspirin $(75-100 \mathrm{mg}$ ) was prescribed for $30 \%$ of the clinic population for primary and secondary prevention of cardiovascular events.

In comparing the services available at WDH to the IDF global guideline recommendations, the WDH diabetes clinic provided care that was below the minimal recommendations for care in 5 domains, met the minimal care recommendations in 7 domains, met the standard care recommendations in 7 domains, and didn't meet the comprehensive care recommendations in any of the domains (Table 7). For the domains where the clinic did not meet minimal recommendations, the primary limitations were related to limited lab infrastructure within the hospital where laboratory tests were infrequently available to patients.

\section{Discussion}

This multifaceted evaluation of the quality of care within the WDH rural diabetes clinic provides insight into the unique aspects of implementing diabetes care in rural SSA. Our investigation revealed a statistically significant $10 \%$ decrease in HbA1c among enrolled diabetes patients, 
Table 2 - Duration of Follow-up for Diabetes Clinic Patients

\begin{tabular}{llll}
\hline Duration of Follow-up & Total $(\mathrm{n}=524)$ & SMBG $(\mathrm{n}=85)$ & Non-SMBG $(\mathrm{n}=436)$ \\
\hline Baseline encounter only $\mathrm{n}(\%)$ & $101(19.2 \%)$ & $6(7.1 \%)$ & $95(21.7 \%)$ \\
At least 1 month & $418(79.7 \%)$ & $78(91.7 \%)$ & $340(77.9 \%)$ \\
3 months & $378(72.1 \%)$ & $75(88.2 \%)$ & $303(69.4 \%)$ \\
6 months & $316(60.3 \%)$ & $66(77.6 \%)$ & $250(57.3 \%)$ \\
9 months & $282(53.8 \%)$ & $62(72.9 \%)$ & $220(50.4 \%)$ \\
12 months & $235(44.8 \%)$ & $58(68.2 \%)$ & $177(40.6 \%)$ \\
15 months & $195(37.2 \%)$ & $51(60.0 \%)$ & $144(33.0 \%)$ \\
$>18$ months & $161(30.7 \%)$ & $42(49.4 \%)$ & $119(27.2 \%)$ \\
\hline
\end{tabular}

SMBG Self-Monitored Blood Glucose

reflecting improved glycemic control. In addition, we noted a high adherence to recommended diabetes care procedures in this resource constrained setting.

HbA1c is a good marker for glycemic control over 3 months and is recommended regularly for patients with DM because of its unique ability to predict complications [16-18]. HbA1c fell significantly over time for the overall clinic population and in particular, among patients with higher baseline HbA1cs. This may have been a result of their preferential enrolment into the intensive SMBG program. While access to SMBG programs are largely unavailable in the public sector in SSA, this service demonstrated a dramatic reduction in $\mathrm{HbA1c}$ for enrollees and is a feasible strategy to stave off costly and difficult to manage diabetes complications in high risk patients [19].

Statistically significant reductions were not seen with $\mathrm{BMI}$ in the overall population, an unsurprising finding considering the initial baseline BMI of the diabetes population revealed a lower frequency of obesity in our population than seen in resource-rich settings [15]. In contrast, patients with $\mathrm{BMI}<18.5 \mathrm{~kg} / \mathrm{m}^{2}$ showed a statistically significant increase in BMI over the course of care, a reflection of the unique pathophysiologic presentation of diabetes in this rural setting [20]. With the atypical low BMI presentation exhibited by these patients, providers were generally more inclined to initiate insulin therapy or insulin secretagogues over metformin therapy as the primary mechanism of action and weight loss associated with metformin would not be desirable amongst these patients [21]. Both insulin and insulin secretagogues are known to trigger weight gain and thus may have contributed to the increase among the patients with a low BMI [22].

Use of standardized encounter forms and point of care glucose and $\mathrm{HbA1c}$ testing ensured regular assessments of recommended diabetes tests and services, with more than $85 \%$ of patients receiving regular HbA1c testing. In contrast, services which could not be performed within the clinic were frequently not provided due to lack of availability of reagents and nonfunctioning equipment in the hospital lab. These findings highlight a frequently observed trend seen with diabetes care in low-resource settings where logistical challenges have a dramatic negative impact on the care of diabetes patients [2, 23-25].

Our investigation has several limitations which are important to highlight. First, multiple points of documentation were required during clinic visits in a somewhat fragmented process that involved documentation in a $\mathrm{MOH}$ diary and a $\mathrm{MOH}$ prescription form, in addition to the standardized encounter form. These cumbersome and time-consuming requirements anecdotally led to documentation fatigue among providers and potentially incomplete documentation in the electronic data

Table 3 - Mean HbA1c at quarterly intervals within the overall, self-monitored blood glucose and regular clinic populations

\begin{tabular}{llll}
\hline Time & $\begin{array}{l}\text { Mean HbA1c (\%) } \pm \text { SD } \\
\text { Overall (evaluable patients) }\end{array}$ & Mean HbA1c $(\%) \pm$ SD Self monitored blood glucose (evaluable patients) & $\begin{array}{l}\text { Mean HbA1c }(\%) \pm S D \\
\text { Regular care (evaluable patients) }\end{array}$ \\
\hline 0 months & $10.2 \pm 2.8(n=421)$ & $12.4 \pm 0.3(n=69)$ & $9.9 \pm 0.1(n=353)$ \\
3 months & $8.9 \pm 2.3(n=130)^{*}$ & $9.6 \pm 0.4(n=34)^{*}$ & $8.6 \pm 0.2(n=96)^{*}$ \\
6 months & $8.7 \pm 2.5(n=123)^{*}$ & $9.7 \pm 0.5(n=26)^{*}$ & $8.5 \pm 0.2(n=101)^{*}$ \\
9 months & $9.2 \pm 2.6(n=129)^{*}$ & $10.1 \pm 0.4(n=41)^{*}$ & $8.8 \pm 0.3(n=85)^{*}$ \\
12 months & $8.5 \pm 2.1(n=87)^{*}$ & $9.6 \pm 0.4(n=25)^{*}$ & $8.1 \pm 0.2(n=62)^{*}$ \\
15 months & $8.3 \pm 1.9(n=83)^{*}$ & $8.9 \pm 0.4(n=25)^{*}$ & $8.0 \pm 0.2(n=58)^{*}$ \\
18 months & $8.5 \pm 2.2(n=69)^{*}$ & $8.5 \pm 0.4(n=27)^{*}$ & $8.4 \pm 0.4(n=42)^{*}$ \\
\hline
\end{tabular}

$S D$ Standard Deviation

${ }^{*} P<0.05$ via paired $t$ test comparing baseline values in each column to subsequent values 
Table 4 - Change in Random Blood Sugar, Systolic Blood Pressure, Diastolic Blood Pressure and Body Mass Index

\begin{tabular}{|c|c|c|c|c|c|}
\hline Time & $\begin{array}{l}\text { RBS (mmol/l) } \\
\text { (mean } \pm \mathrm{SD}, \\
\text { evaluable } \\
\text { population) }\end{array}$ & $\begin{array}{l}\text { Systolic Blood } \\
\text { pressure }(\mathrm{mmHg}) \\
\text { (mean } \pm \mathrm{SD}, \\
\mathrm{n}=\text { evaluable } \\
\text { population) }\end{array}$ & $\begin{array}{l}\text { Diastolic Blood } \\
\text { pressure }(\mathrm{mmHg}) \\
\text { (mean } \pm \mathrm{SD}, \mathrm{n}=\text { evaluable } \\
\text { population) }\end{array}$ & $\begin{array}{l}\text { BMI Males }\left(\mathrm{kg} / \mathrm{m}^{2}\right) \\
(\text { mean } \pm \mathrm{SD} \\
\mathrm{n}=\text { evaluable } \\
\text { population) }\end{array}$ & $\begin{array}{l}\text { BMl Females }\left(\mathrm{kg} / \mathrm{m}^{2}\right) \\
(\text { mean } \pm \mathrm{SD}, \\
\mathrm{n}=\text { evaluable } \\
\text { population) }\end{array}$ \\
\hline 0 months & $10.7 \pm 4.9(n=512)$ & $134 \pm 24(n=514)$ & $83 \pm 12(n=514)$ & $26.0 \pm 9.0(n=150)$ & $27.6 \pm 6.5(n=202)$ \\
\hline 3 months & $8.9 \pm 3.6(n=364)^{*}$ & $136 \pm 21(n=364)$ & $83 \pm 11(n=364)$ & $26.3 \pm 6.2(n=125)$ & $27.7 \pm 6.3(n=179)$ \\
\hline 6 months & $9.2 \pm 4.0(n=284)^{*}$ & $136 \pm 21(n=289)$ & $82 \pm 11(n=289)$ & $25.9 \pm 5.9(n=102)$ & $27.6 \pm 5.6(n=159)$ \\
\hline 9 months & $9.6 \pm 4.2(n=260)$ & $135 \pm 20(n=266)$ & $82 \pm 11(n=266)$ & $26.3 \pm 6.1(n=92)$ & $27.5 \pm 6.4(n=143)$ \\
\hline 12 months & $8.9 \pm 3.8(n=217)^{*}$ & $137 \pm 21(n=225)$ & $83 \pm 13(n=225)$ & $26.4 \pm 6.3(n=80)$ & $27.7 \pm 6.3(n=117)$ \\
\hline 15 months & $9.0 \pm 3.5(n=183)$ & $134 \pm 22(n=188)$ & $81 \pm 12(n=188)$ & $26.8 \pm 6.1(n=75)$ & $28.3 \pm 6.8(n=92)$ \\
\hline 18 months & $9.1 \pm 4.1 \quad(n=157)$ & $136 \pm 22(n=157)$ & $83 \pm 11(n=157)$ & $26.8 \pm 6.7(n=68)$ & $28.0 \pm 5.7(n=74)$ \\
\hline
\end{tabular}

RBS Random Blood Sugar, BMI Body Mass Index

${ }^{*} \mathrm{P}<0.05$ via paired $\mathrm{t}$ test comparing baseline values in each column to subsequent values

collection tool. Despite the challenges associated with documentation, the standardized clinical encounter form was crucial to ensuring that the clinic met many of the recommended minimum standards set forth in the IDF guidelines. Second, use of a retrospective assessment over a fixed time period led to varying periods of follow-up for the evaluated patients. $60 \%$ of the patients had follow up data for at least 6 months while only $31 \%$ of patients had follow up data for at least 18 months. While this approach had multiple challenges with missing data, this approach gives readers a realistic view of the initial observations seen when establishing a specialty diabetes clinic in a rural setting. While it would have been ideal to have 18 months of data on all patients, we were only able to follow a small subset of patients for the entire duration because of the varying dates of enrollment of participants. It is also possible that this follow-up approach could have introduced selection bias as patients who remained engaged in care for 18 months might be more likely to have better outcomes than patients who contributed data over a shorter duration of time. Fortunately, this limitation is mitigated by the low rates of patients lost to follow-up. The clinic was not structured to track the reasons for patients being lost to follow up. Third, the WDH clinic received philanthropic support from several sources which was used to offset the costs of vital laboratory tests and expensive medications such as HbA1c and insulin. This limits generalizability to diabetes clinics where patients shoulder all costs of care and medicines. Nevertheless, our findings suggest that logistical considerations can be effectively addressed if many of the financial barriers are overcome or partially subsidized. Another limitation is that patients with type 1 and type 2 diabetes were

Table 5 - Progression of BMI based on initial BMI classification

\begin{tabular}{|c|c|c|c|c|c|c|c|}
\hline BMI basal group $\left(\mathrm{kg} / \mathrm{m}^{2}\right)$ & $\begin{array}{l}0 \text { months } \\
\text { (mean } \pm \text { SD, } \\
n=\text { evaluable } \\
\text { population) }\end{array}$ & $\begin{array}{l}3 \text { months } \\
\text { (mean } \pm \text { SD, } \\
n=\text { evaluable } \\
\text { population) }\end{array}$ & $\begin{array}{l}6 \text { months } \\
\text { (mean } \pm \text { SD, } \\
\mathrm{n}=\text { evaluable } \\
\text { population) }\end{array}$ & $\begin{array}{l}9 \text { months } \\
\text { (mean } \pm \mathrm{SD} \\
\mathrm{n}=\text { evaluable } \\
\text { population) }\end{array}$ & $\begin{array}{l}12 \text { months } \\
\text { (mean } \pm \mathrm{SD}, \\
\mathrm{n}=\text { evaluable } \\
\text { population) }\end{array}$ & $\begin{array}{l}15 \text { months } \\
\text { (mean } \pm \text { SD, } \\
\mathrm{n}=\text { evaluable } \\
\text { population) }\end{array}$ & $\begin{array}{l}18 \text { months } \\
\text { (mean } \pm \text { SD, } \\
\mathrm{n}=\text { evaluable } \\
\text { population) }\end{array}$ \\
\hline$<18.5$ & $\begin{array}{l}16.6 \pm 0.3 \\
n=33\end{array}$ & $\begin{array}{l}18.2 \pm 0.5^{*} \\
n=25\end{array}$ & $\begin{array}{l}18.4 \pm 0.5^{*} \\
n=22\end{array}$ & $\begin{array}{l}18.7 \pm 0.6^{*} \\
n=21\end{array}$ & $\begin{array}{l}19.4 \pm 0.6^{*} \\
n=20\end{array}$ & $\begin{array}{l}19.5 \pm 0.7^{*} \\
n=17\end{array}$ & $\begin{array}{l}20.0 \pm 0.6^{*} \\
n=17\end{array}$ \\
\hline $18.5-24.99$ & $\begin{array}{l}22.2 \pm 0.2 \\
n=108\end{array}$ & $\begin{array}{l}23.0 \pm 0.3 \\
n=87\end{array}$ & $\begin{array}{l}22.6 \pm 0.3 \\
n=71\end{array}$ & $\begin{array}{l}22.9 \pm 0.3 \\
n=67\end{array}$ & $\begin{array}{l}22.9 \pm 0.3 \\
n=54\end{array}$ & $\begin{array}{l}23.0 \pm 0.3 \\
n=38\end{array}$ & $\begin{array}{l}23.2 \pm 0.4 \\
n=32\end{array}$ \\
\hline $25-29.99$ & $\begin{array}{l}27.2 \pm 0.1 \\
n=116\end{array}$ & $\begin{array}{l}27.4 \pm 0.2 \\
n=97\end{array}$ & $\begin{array}{l}27.6 \pm 0.2 \\
n=89\end{array}$ & $\begin{array}{l}27.2 \pm 0.3 \\
n=72\end{array}$ & $\begin{array}{l}27.5 \pm 0.3 \\
n=61\end{array}$ & $\begin{array}{l}27.2 \pm 0.3 \\
n=50\end{array}$ & $\begin{array}{l}27.6 \pm 0.3 \\
n=43\end{array}$ \\
\hline $30-34.99$ & $\begin{array}{l}32.1 \pm 0.2 \\
n=60\end{array}$ & $\begin{array}{l}32.1 \pm 0.3 \\
n=52\end{array}$ & $\begin{array}{l}32.2 \pm 0.4 \\
n=44\end{array}$ & $\begin{array}{l}32.8 \pm 0.6 \\
n=43\end{array}$ & $\begin{array}{l}32.2 \pm 0.6 \\
n=34\end{array}$ & $\begin{array}{l}32.6 \pm 0.5 \\
n=36\end{array}$ & $\begin{array}{l}32.9 \pm 0.6 \\
n=32\end{array}$ \\
\hline $35-39.99$ & $\begin{array}{l}36.4 \pm 0.3 \\
n=21\end{array}$ & $\begin{array}{l}35.3 \pm 0.7 \\
n=18\end{array}$ & $\begin{array}{l}35.3 \pm 0.8 \\
n=16\end{array}$ & $\begin{array}{l}35.3 \pm 0.9 \\
n=14\end{array}$ & $\begin{array}{l}35.5 \pm 1.1 \\
n=11\end{array}$ & $\begin{array}{l}34.9 \pm 1.3 \\
n=11\end{array}$ & $\begin{array}{l}36.1 \pm 1.5 \\
n=7\end{array}$ \\
\hline$>40$ & $\begin{array}{l}49.4 \pm 4.5 \\
n=14\end{array}$ & $\begin{array}{l}45.5 \pm 1.8 \\
n=10\end{array}$ & $\begin{array}{l}44.0 \pm 1.9 \\
n=6\end{array}$ & $\begin{array}{l}44.4 \pm 3.4 \\
n=6\end{array}$ & $\begin{array}{l}44.9 \pm 3.0 \\
n=7\end{array}$ & $\begin{array}{l}45.7 \pm 3.5 \\
n=6\end{array}$ & $\begin{array}{l}46.7 \pm 3.8 \\
n=3\end{array}$ \\
\hline Total & $\begin{array}{l}26.9 \pm 0.4 \\
n=352\end{array}$ & $\begin{array}{l}27.2 \pm 0.4 \\
n=289\end{array}$ & $\begin{array}{l}27.1 \pm 0.4 \\
n=248\end{array}$ & $\begin{array}{l}27.1 \pm 0.4 \\
n=223\end{array}$ & $\begin{array}{l}27.3 \pm 0.5 \\
n=187\end{array}$ & $\begin{array}{l}27.8 \pm 0.5 \\
n=158\end{array}$ & $\begin{array}{l}27.7 \pm 0.5 \\
n=134\end{array}$ \\
\hline
\end{tabular}


Table 6 - Diabetes associated complications in the self-monitored blood glucose vs regular care groups

\begin{tabular}{|c|c|c|c|c|c|c|c|c|c|c|}
\hline \multirow[t]{2}{*}{ Time } & \multicolumn{5}{|c|}{ Self-monitored blood glucose } & \multicolumn{5}{|c|}{ Regular Care } \\
\hline & $\bar{N}$ & $\begin{array}{l}\text { Peripheral } \\
\text { neuropathy } \\
\text { events }(n, \%)\end{array}$ & $\begin{array}{l}\text { Ocular } \\
\text { events } \\
(n, \%) \\
\end{array}$ & $\begin{array}{l}\text { Hypo-glycemic } \\
\text { episodes } \\
(n, \%)\end{array}$ & $\begin{array}{l}\text { Hyper-glycemic } \\
\text { episodes } \\
(n, \%)\end{array}$ & $\bar{N}$ & $\begin{array}{l}\text { Peripheral } \\
\text { neuropathy } \\
\text { events }(n, \%)\end{array}$ & $\begin{array}{l}\text { Ocular } \\
\text { events } \\
(n, \%) \\
\end{array}$ & $\begin{array}{l}\text { Hypo-glycemic } \\
\text { episodes } \\
(n, \%)\end{array}$ & $\begin{array}{l}\text { Hyper-glycemic } \\
\text { episodes } \\
(n, \%)\end{array}$ \\
\hline 0 months & 85 & $46(54 \%)$ & $45(53 \%)$ & $43(51 \%)$ & $68(80 \%)$ & 440 & $232(53 \%)$ & $243(55 \%)$ & $98(22 \%)$ & $162(37 \%)$ \\
\hline 3 months & 71 & $42(59 \%)$ & $39(55 \%)$ & $50(70 \%)^{*}$ & $25(35 \%)^{*}$ & 296 & $170(57 \%)^{*}$ & $156(53 \%)^{*}$ & $84(28 \%)^{*}$ & $44(15 \%)^{*}$ \\
\hline 6 months & 59 & $33(56 \%)$ & $31(53 \%)$ & $30(51 \%)$ & $27(46 \%)^{*}$ & 230 & $125(54 \%)^{*}$ & $124(54 \%)$ & $69(30 \%)^{*}$ & $55(24 \%)^{*}$ \\
\hline 9 months & 58 & $33(57 \%)$ & $29(50 \%)$ & $36(62 \%)^{*}$ & $32(55 \%)^{*}$ & 208 & $106(51 \%)^{*}$ & $87(42 \%)^{*}$ & $66(32 \%)^{*}$ & $41(20 \%)^{*}$ \\
\hline 12 months & 55 & $27(49 \%)$ & $27(49 \%)$ & $29(53 \%)^{*}$ & $10(18 \%)^{*}$ & 170 & $78(46 \%)$ & $76(45 \%)^{*}$ & $33(19 \%)^{*}$ & $25(15 \%)^{*}$ \\
\hline 15 months & 50 & $23(46 \%)$ & $27(54 \%)$ & $16(32 \%)^{*}$ & $20(40 \%)^{*}$ & 138 & $64(46 \%)^{*}$ & $52(38 \%)^{*}$ & $24(17 \%)^{*}$ & $27(20 \%)^{*}$ \\
\hline 18 months & 43 & $17(40 \%)^{*}$ & $17(40 \%)^{*}$ & $17(40 \%)^{*}$ & $5(12 \%)^{*}$ & 114 & $44(39 \%)^{*}$ & $39(34 \%)^{*}$ & $16(14 \%)^{*}$ & $17(15 \%)^{*}$ \\
\hline
\end{tabular}

*P $<0.05$ as compared to its own basal value ( 0 months) (calculated with a binomial test)

analysed together in the same cohort. This analysis strategy was utilized to ensure that the process measures analysed in this study reflected the entire population receiving care in the clinic and were representative of the patient population typically seen in SSA. This decision to analyse patients in a combined fashion was influenced by several of the limitations we have observed within this population and the limited infrastructure in this setting. This includes the frequent observation that patients with type 1 diabetes in SSA tend to have delayed onset of type 1 diabetes compared to other settings and have a relatively higher presence of atypical variants of diabetes which require unique treatment regimens incorporating intermittent insulin [20, 26-28]. Furthermore, the WDH clinic, like most public sector diabetes clinics in SSA, does not have the capacity to perform C-peptide or antibody testing to help confirm the presence of type 1 diabetes [19]. These factors make it difficult to appropriately categorize patients as having type 1 or type 2 diabetes. While this represents a limitation of this study, it is worth noting that only $3 \%$ of the population was $<20$ years of age at the time of enrollment.

Table 7 - Grading of the WDH clinic structure metrics against the International Diabetes Federation Guidelines

\begin{tabular}{|c|c|c|c|c|}
\hline IDF Domains & Below minimal care & $\begin{array}{l}\text { Minimal } \\
\text { Care }\end{array}$ & $\begin{array}{l}\text { Standard } \\
\text { Care }\end{array}$ & $\begin{array}{l}\text { Comprehensive } \\
\text { Care }\end{array}$ \\
\hline Screening & & $x$ & & \\
\hline Care delivery & & & $x$ & \\
\hline Education & & & $x$ & \\
\hline Psychological Care & $X$ - Limited access to mental health care referral and medications & & & \\
\hline Lifestyle management & & $x$ & & \\
\hline Glucose control Targets & & $x$ & & \\
\hline Clinical Monitoring & & & $x$ & \\
\hline Self-monitoring & & & $x$ & \\
\hline Glucose control: oral therapy & & $x$ & & \\
\hline $\begin{array}{l}\text { Glucose control: insulin } \\
\text { therapy }\end{array}$ & & & $x$ & \\
\hline Blood pressure control & & & $x$ & \\
\hline Cardiovascular risk protection & X-Statins infrequently used/available & & & \\
\hline Eye Screening & & $x$ & & \\
\hline Kidney damage & X-limited assessment for proteinuria or routine creatinine & & & \\
\hline Foot care & & $x$ & & \\
\hline Nerve damage & & $x$ & & \\
\hline Pregnancy & X-Approved methods for diabetes screening not routinely done & & & \\
\hline Children & & & $x$ & \\
\hline In-patient care & $\begin{array}{l}\text { X-Limited access to intensive care and limited biochemistry } \\
\text { capacity }\end{array}$ & & & \\
\hline
\end{tabular}


Despite these limitations, our comprehensive analysis provides an in-depth assessment of the unique aspects of providing care in rural resource-limited settings in SSA. The improvements in the glucose control of the population, highlights how barriers to care can be overcome through collaborative partnerships including local providers, international funders, and academic institutions. This analysis has also provided our overarching diabetes clinic operations team with considerable guidance on how to promote continuous quality improvement within our service delivery. In order to address the domains in which the WDH clinic failed to meet the recommended IDF criteria standards for quality care, we have specifically addressed many of the limitations of the clinic by including programs which have studied the ideal methods for assessing gestational diabetes [29], assessed the reliability of point of care lipid testing [30], incorporated point of care testing for creatinine and potassium, tested various screening approaches [31], incorporated additional medications such as statins within the clinic pharmacy [13, 32, 33], implemented community based diabetes care delivery alongside microfinance services [34], and included a mobile point of care electronic medical record system eliminating the need for duplicative data entry [35-37].

\section{Conclusion}

This comprehensive analysis highlights many unique attributes found in a rural diabetes clinic in western Kenya. With the projected increases in diabetes prevalence across SSA, it is essential that lessons are learned from this analysis and responsive, contextualized infrastructure is created to continue expanding access to high quality diabetes services across the region. The many gaps in care and unique attributes found amongst this patient population create a rich platform for future research efforts geared towards addressing the many pressing challenges patients with diabetes in SSA face. A combined approach which simultaneously focuses on the creation of much needed clinical infrastructure for comprehensive diabetes care with contextualized research will help stave off the many anticipated health and economic consequences associated with diabetes in SSA.

\section{Additional file}

Additional file 1: Global Guideline for Type 2 Diabetes. (PDF 533 kb)

\section{Abbreviations}

AMPATH: Academic Model Providing Access to Healthcare; BMl: Body mass index; CVD: Cardiovascular Disease; DM: Diabetes Mellitus;

HbA1c: Glycosylated hemoglobin; HIV: Human immunodeficiency virus; IDF: International Diabetes Federation; IQR: Interquartile range; IUPUI: Indiana University Purdue University Indianapolis; mmHg: Millimeters mercury;
$\mathrm{MOH}$ : Ministry of Health; NCD: Non-communicable diseases; RBS: Random blood sugar; SD: Standard deviation; SEM: Standard error of the mean; SMBG: Self-monitored blood glucose; SSA: Sub-Saharan Africa; USAID: United States Agency for International Development; VA: Veterans Affairs; WDH: Webuye District Hospital

\section{Acknowledgements}

Not applicable.

\section{Funding}

This research was supported in part by the President's Emergency Plan for AIDS Relief through the U.S. Agency for International Development under the terms of Cooperative Agreement No. AID-623-A-12-0001. The contents of this article are the sole responsibility of AMPATH and do not necessarily reflect the views of USAID or the U.S. government. This publication was also made possible by the Indiana Clinical and Translational Sciences Institute, funded in part by grant UL1 TR001108 from the National Institutes of Health, National Center for Advancing Translational Sciences, Clinical and Translational Sciences Award. The authors thank Abbott Diabetes Care for providing glucose testing supplies and the Abbott Fund for providing financial support for this effort. They also thank Eli Lilly and Company for donating insulin and providing seed funding to support the authors' overarching work in diabetes. They also thank the Miriam Hospital (Providence, RI) and Mennonite Central Committee for their initial financial support in establishing this clinic.

\section{Availability of data and materials}

The datasets used and/or analyzed during the current study are available from the corresponding author on reasonable request.

\section{Authors' contributions}

$\mathrm{SP}, \mathrm{CP}, \mathrm{BN}$, and $\mathrm{EO}$ were significant contributors to the writing of this manuscript and interpreted data set results. BNB and SC analyzed and interpreted data sets related to patient outcomes. PC, JL, VB and NK had significant oversight of data collection and intervention implementation in the clinical setting. All authors read and approved the final manuscript.

\section{Ethical approval and consent to participate}

This study was approved by the Moi Teaching and Referral Hospital/Moi University School of Medicine Institutional Research and Ethics Committee and the Institutional Review Board of the Indiana University Purdue University Indianapolis (IUPUI). A waiver of informed consent was obtained from both of the institutions as all data being assessed was collected through routine clinical care and was de-identified before being retrospectively assessed.

\section{Consent for publication}

Not applicable.

\section{Competing interests}

Sonak Pastakia serves as a consultant for Abbott on work unrelated to the study being presented here. The other authors declare that they have no competing interests.

\section{Publisher's Note}

Springer Nature remains neutral with regard to jurisdictional claims in published maps and institutional affiliations.

\footnotetext{
Author details

${ }^{1}$ Moi University School of Medicine, Nandi Hills Road, Eldoret 30100, Kenya. ${ }^{2}$ USAID-Academic Model Providing Access to Healthcare (AMPATH) /Moi Teaching and Referral Hospital, Nandi Hills Road, Eldoret 30100, Kenya. ${ }^{3}$ Purdue Kenya Partnership, Purdue University College of Pharmacy, PO Box 5760, Eldoret 30100, Kenya. ${ }^{4}$ Webuye District Hospital, PO Box 25, Webuye Road, Webuye 50205, Kenya. ${ }^{5}$ National Institute of Diabetes and Digestive and Kidney Diseases, National Institutes of Health, 31 Center Dr, Bethesda, MD 20892, USA. 'Ohio State University, College of Pharmacy, 500 W 12th Ave, Parks Hall, Columbus, OH 43210, USA. ${ }^{7}$ New Mexico VA Health Care System, 1501 San Pedro SE, Albuquerque, NM, USA.
} 
Received: 17 September 2018 Accepted: 11 December 2018 Published online: 27 December 2018

\section{References}

1. Worldwide trends in diabetes since 1980: a pooled analysis of 751 population-based studies with 4.4 million participants. Lancet. 2016; 387(10027):1513-30

2. Atun R, Davies Jl, Gale EAM, Barnighausen T, Beran D, Kengne AP, et al. Diabetes in sub-Saharan Africa: from clinical care to health policy. Lancet Diabetes Endocrinol. 2017;5(8):622-67.

3. IDF Diabetes Atlas 8th Edition. 2017. Available from: http://diabetesatlas.org/ resources/2017-atlas.html.

4. Azevedo M, Alla S. Diabetes in sub-Saharan Africa: Kenya, Mali, Mozambique, Nigeria, South Africa and Zambia. International Journal of Diabetes in Developing Countries. 2008;28(4):101-8.

5. Pastakia SD, Karwa R, Kahn CB, Nyabundi JS. The evolution of diabetes care in the rural, resource-constrained setting of western Kenya. Ann Pharmacother. 2011;45(6):721-6.

6. IDF Diabetes Atlas 7th Edition. 2015. Available from: https://www.idf.org/e-library/ epidemiology-research/diabetes-atlas/13-diabetes-atlas-seventh-edition.html.

7. Beran D, Yudkin JS, de Courten M. Access to care for patients with insulinrequiring diabetes in developing countries: case studies of Mozambique and Zambia. Diabetes Care. 2005;28(9):2136-40.

8. Peck R, Mghamba J, Vanobberghen F, Kavishe B, Rugarabamu V, Smeeth L, et al. Preparedness of Tanzanian health facilities for outpatient primary care of hypertension and diabetes: a cross-sectional survey. Lancet Glob Health. 2014;2(5):e285-92

9. World Urbanization Prospects: The 2014 Revision Population Dataset. https://esa.un.org/unpd/wup/publications/files/wup2014-highlights.pdf.

10. Urbanization in Africa [updated December 2012]. Available from: http:// www.afdb.org/en/blogs/afdb-championing-inclusive-growth-across-africa/ post/urbanization-in-africa-10143/.

11. International Diabetes Federation Clinical Guidelines Task Force. Global Guidelines for Type 2 Diabetes. In: International Diabetes Federation; 2005.

12. Einterz RM, Kimaiyo S, Mengech HN, Khwa-Otsyula BO, Esamai F, Quigley F, et al. Responding to the HIV pandemic: the power of an academic medical partnership. Acad Med. 2007:82(8):812-8.

13. Manji I, Manyara SM, Jakait B, Ogallo W, Hagedorn IC, Lukas S, et al. The revolving fund pharmacy model: backing up the Ministry of Health supply chain in western Kenya. Int J Pharm Pract. 2016;24(5):358-66.

14. Pastakia SD, Cheng SY, Kirui NK, Kamano JH. Dynamics, impact, and feasibility of self-monitoring of blood glucose in the rural, resourceconstrained setting of Western Kenya. Clin Diabetes. 2015;33(3):136-43.

15. O'Hara EG, Nuche-Berenguer B, Kirui NK, Cheng SY, Chege PM, Buckwalter V, et al. Diabetes in rural Africa: what can Kenya show us? Lancet Diabetes Endocrinol. 2016:4(10):807-9.

16. International Diabetes Federation. Recommendations For Managing Type 2 Diabetes In Primary Care, 2017. www.idf.org/managing-type2-diabetes.

17. The relationship of glycemic exposure $(\mathrm{HbA} 1 \mathrm{c})$ to the risk of development and progression of retinopathy in the diabetes control and complications trial. Diabetes. 1995;44(8):968-83.

18. Stratton IM, Adler Al, Neil HA, Matthews DR, Manley SE, Cull CA, et al. Association of glycaemia with macrovascular and microvascular complications of type 2 diabetes (UKPDS 35): prospective observational study. BMJ. 2000;321(7258):405-12.

19. PATH. Diabetes supplies: are they there when needed? PATH: Seattle; 2015.

20. Mbanya JC, Motala AA, Sobngwi E, Assah FK, Enoru ST. Diabetes in subSaharan Africa. Lancet. 2010;375(9733):2254-66.

21. Partners in health guidelines for type 2 diabetes management in lowand middle-income countries. Adapted from Kidder A, Kwan G, Cancedda C, Bukhman G. Diabetes. In: Bukhman G, Kidder A, editors. The PIH guide to chronic care integration for endemic noncommunicable diseases. Rwanda ed. Boston, MA: Partners in Health; 2011. p. 153-87. Copyright (c) 2011 Partners in health. All rights reserved under International and Pan-American Copyright Conventions.

22. Russell-Jones D, Khan R. Insulin-associated weight gain in diabetes--causes, effects and coping strategies. Diabetes Obes Metab. 2007;9(6):799-812.

23. American Diabetes Association. Strategies for Improving Care. Diabetes Care. 2016;39(Supplement 1):S6-S12.
24. Shojania KG, Ranji SR, McDonald KM, Grimshaw JM, Sundaram V Rushakoff RJ, et al. Effects of quality improvement strategies for type 2 diabetes on glycemic control: a meta-regression analysis. JAMA. 2006:296(4):427-40.

25. Ricci-Cabello I, Ruiz-Perez I, Rojas-García A, Pastor G, Gonçalves DC. Improving diabetes Care in Rural Areas: a systematic review and metaanalysis of quality improvement interventions in OECD countries. PLoS One. 2013;8(12):e84464.

26. Alemu S, Dessie A, Seid E, Bard E, Lee PT, Trimble ER, et al. Insulin-requiring diabetes in rural Ethiopia: should we reopen the case for malnutritionrelated diabetes? Diabetologia. 2009;52(9):1842-5.

27. Kalk WJ, Huddle KR, Raal FJ. The age of onset and sex distribution of insulin-dependent diabetes mellitus in Africans in South Africa. Postgrad Med J. 1993;69(813):552-6.

28. Pastakia SD, Pekny CR, Manyara SM, Fischer L. Diabetes in sub-Saharan Africa - from policy to practice to progress: targeting the existing gaps for future care for diabetes. Diabetes Metab Syndr Obes. 2017;10:247-63.

29. Pastakia SD, Njuguna B, Onyango BA, Washington S, Christoffersen-Deb A, Kosgei WK, et al. Prevalence of gestational diabetes mellitus based on various screening strategies in western Kenya: a prospective comparison of point of care diagnostic methods. BMC Pregnancy and Childbirth. 2017; 17(1):226

30. Park PH, Chege P, Hagedorn IC, Kwena A, Bloomfield GS, Pastakia SD. Assessing the accuracy of a point-of-care analyzer for hyperlipidaemia in western Kenya. Tropical Med Int Health. 2016;21(3):437-44.

31. Pastakia SD, Ali SM, Kamano JH, Akwanalo CO, Ndege SK, Buckwalter VL, et al. Screening for diabetes and hypertension in a rural low income setting in western Kenya utilizing home-based and community-based strategies. Glob Health. 2013;9:21.

32. Pastakia S, Manji I, Mercer T. Noncommunicable diseases and essential medicines. Health Aff (Millwood). 2015:34(11):2003.

33. Binanay CA, Akwanalo CO, Aruasa W, Barasa FA, Corey GR, Crowe S, et al. Building sustainable capacity for cardiovascular Care at a Public Hospital in Western Kenya. J Am Coll Cardiol. 2015;66(22):2550-60

34. Pastakia SD, Manyara SM, Vedanthan R, Kamano JH, Menya D, Andama B, et al. Impact of bridging income generation with group integrated care (BIGPIC) on hypertension and diabetes in rural Western Kenya. J Gen Intern Med. 2017;32(5):540-8

35. Blank E, Tuikong N, Misoi L, Kamano J, Hutchinson C, Kimaiyo S, et al. Usability of Implementing a Tablet-Based Decision Support and Integrated Record-Keeping (DESIRE) Tool in the Nurse Management of Hypertension in Rural Kenya. Studies in health technology and informatics. 2013;192:1002.

36. Bloomfield GS, Vedanthan R, Vasudevan L, Kithei A, Were M, Velazquez EJ. Mobile health for non-communicable diseases in sub-Saharan Africa: a systematic review of the literature and strategic framework for research. Glob Health. 2014;10:49.

37. Rajput ZA, Mbugua S, Amadi D, Chepnǵeno V, Saleem JJ, Anokwa Y, et al. Evaluation of an android-based mHealth system for population surveillance in developing countries. Journal of the American Medical Informatics Association : JAMIA 2012:19(4):655-9.

Ready to submit your research? Choose BMC and benefit from:

- fast, convenient online submission

- thorough peer review by experienced researchers in your field

- rapid publication on acceptance

- support for research data, including large and complex data types

- gold Open Access which fosters wider collaboration and increased citations

- maximum visibility for your research: over $100 \mathrm{M}$ website views per year

At $\mathrm{BMC}$, research is always in progress.

Learn more biomedcentral.com/submission 